\title{
A REVIEW OF THE SURFACE MODIFICATIONS OF TITANIUM ALLOYS FOR BIOMEDICAL APPLICATIONS
}

\author{
PREGLED MODIFIKACIJ POVRŠINE TITANOVIH ZLITIN ZA \\ BIOMEDICINSKO UPORABO
}

\author{
Mallaiah Manjaiah, Rudolph Frans Laubscher \\ University of Johannesburg, Department of Mechanical Engineering Science, Kingsway Campus, Auckland Park, \\ 2006 Johannesburg, South Africa \\ manjaiahgalpuji@gmail.com
}

Prejem rokopisa - received: 2015-12-18; sprejem za objavo - accepted for publication: 2016-03-02 doi:10.17222/mit.2015.348

\begin{abstract}
Dental implants are mechanical components that are used to restore the mastication (chewing) function and/or aesthetic appeal because of tooth loss or degradation. They are affixed (screwed) into the upper or lower jaw and act as a base for single or bridge-type tooth replacements. They are mostly manufactured from titanium alloys. The surface integrity of the manufactured implant may have a significant effect on the functioning and success of the implant. A systematic review is described on the effect of engineered surface integrity on the performance of titanium dental implants as regards the implant fixation, mechanical performance, bone growth and cell response. The need for surface engineering of the implant is introduced first. This includes the mechanical, surface-integrity and biocompatibility-required properties. This is followed by introducing and discussing the dedicated surface-modification processes currently employed. These include: abrasive blasting, electrochemical processes, hybrid processes and laser modification. The mechanical and biocompatible properties of an implant are the most crucial factor for their application in biomedical use. Hence, the present review article focused on the latest improvements to dental implant design based on the mechanical and biocompatible properties. The physical contact of an implant with respect to its surface roughness is an important factor in dental implant design. The surface roughness of an implant on the macro, micro and nano scales have specific effects on the implant's contact with the surrounding tissue of the bone. In addition, the biocompitability of titanium material is very important to develop a sustainable dental implant. Looking into the importance of the above mechanical and biocompatible properties of bone implants, the authors review elaborately the development of titanium-based implants with reference to the above properties.
\end{abstract}

Keywords: implants, titanium, surface roughness, systematic review, surface engineering process, hybrid process, mechanical machining, chemical treatment

Zobni vsadki so mehanske komponente, ki se jih uporablja za obnovo funkcije žvečenja in/ali iz estetskih razlogov zaradi izgube ali poslabšanja zoba. Pritrjeni (privijačeni) so v zgornjo ali v spodnjo čeljust in služijo kot osnova za nadomestni zob ali za mostiček. Večinoma so izdelani iz titanovih zlitin. Integriteta površine izdelanih vsadkov lahko pomembno vpliva na delovanje in uspešnost vsadka. Opisan je sistematičen pregled o vplivu inženirske celovitosti površine na zmogljivost titanovega dentalnega vsadka glede na pritrditev vsadka, mehanske zmogljivosti, vraščanja kosti in odziva celic. Najprej je predstavljena potreba po obdelavi površine vsadka. To vključuje zahtevane mehanske lastnosti, celovitost površine in biokompatibilnost. Temu sledi predstavitev in razlaga trenutno uporabljanih postopkov za namensko spremembo površine. To vključuje: abrazivno peskanje, elektrokemijske procese, hibridne procese in modifikacijo z laserjem. Mehanske in biokompatibilne lastnosti vsadka so najbolj pomemben faktor pri njihovi uporabi v biomedicini. Zato ta članek predstavlja najnovejši razvoj za izboljšanje načrtovanja dentalnega vsadka na podlagi mehanskih in biokompatibilnih lastnostih. Fizični stik vsadka, glede na hrapavost površine, je pomemben faktor pri načrtovanju vsadka. Hrapavost površine vsadka ima na makro-, mikro- in nanonivoju specifičen vpliv na stik vsadka z obkrožujočim tkivom kosti. Poleg tega je biokompatibilnost titanovega materiala pomembna za razvoj trajnostnih dentalnih vsadkov. Zaradi pomembnosti mehanskih in biokompatibilnih lastnosti kostnih vsadkov avtorji prikazujejo, glede na te lastnosti, razvoj vsadkov na osnovi titana.

Ključne besede: vsadki, titan, hrapavost površine, sistematičen pregled, postopki spreminjanja površine, hibridni proces, mehanska, kemijska obdelava

\section{INTRODUCTION}

A significant portion of the population may have a need for implant dentistry to restore the mastication (chewing) function or aesthetic appeal after losing teeth because of disease or mechanical trauma. Dental implants are mechanical components that are affixed (screwed) into the jawbone and act as the base for single or bridge-type tooth replacement. They are mostly manufactured from titanium alloys. Dentists and dental specialists encounter various challenges regarding the placement of implants into the jawbone structure. They are continuously seeking new methods and alternative materials to solve the many challenges at hand while reducing the risks involved. Dental implants are the nearest equivalent replacement to a natural tooth that may be compromised by disease or trauma. A dental implant is a metal part and therefore a foreign body as far as the physiology of the patient is concerned. This may lead to several difficulties such as compatibility with the rest of the body. Successful application implies that the dental specialist industry considers all the relevant factors as related to dental reconstruction and restoration. These factors may include the implant geometric 
design, mechanical performance, aesthetic appeal, biocompatibility and osseointegration of the implant with the bone and surrounding tissues. Dental implants can be categorized into three widely used designs. These are subperoisteal, transosteal and the more recent and most popular of the three the endosseous implants. The endosseous types are placed deep within the mandible or maxilla, the lower and upper jawbone, respectively. Once the implant is placed (usually screwed) within the jaw and left to heal, the jawbone osseointegrates with the implant to create a secure interface between jaw and implant. Successful osseointegration, as far as mechanical performance is concerned, is assessed by the implant withstanding a certain minimum loosening torque, usually applied with a torque wrench.

Prosthetic and implant manufacture include various different types of designs, shapes and surface-engineered components made from various materials. Biocompatible materials that have been and are used include stainless steel, carbon, platinum, titanium, silver, cobalt chrome alloys, alumina, magnesium, sapphire, acrylic, porcelain, calcium phosphate compounds and zirconia.

Dental and orthopedic practitioners have previously used stainless steel and cobalt-chrome alloys for their implants. These materials have good mechanical properties such as high strength and good corrosion resistance. Furthermore, they have proven to be compatible with the human body. They demonstrated clinical success in many implant cases. ${ }^{1}$ However, titanium and its alloys have largely superseded them because of similar and enhanced properties. Titanium is inert and has good biocompatibility. It resists a wide range of corrosive agents and has a superior strength-to-weight ratio when compared to that of steel. Today, dental practitioners mainly use commercially pure titanium as their material of choice. The clinical success of any biomedical orthopedic/dental implant depends on the surface interaction between the bone tissue and the implant (osseointegration). Hence, the dentists/orthopaedists must make use of an implant manufactured from a suitable material that also has a suitable surface integrity. In general, Ti alloys are more corrosion resistant and less toxic when used in the human body compared to steel, $\mathrm{Co}-\mathrm{Cr}$ and tantalum. ${ }^{2}$ The fact that titanium alloys also have a lower elastic modulus, more comparable with that of bone, helps with the load transfer and subsequent stress profile at the interface. Titanium-based alloys have therefore become the material of choice for many implant applications because of their outstanding characteristics, such as high tensile strength, corrosion resistance, lower modulus of elasticity, lower density and enhanced biocompatibility (osseointegration ability). Apart from these applications, titanium alloys have a wide range of applications in other commercial and aerospace industries.

\subsection{Required mechanical and biocompatible properties of implant materials}

The selection of a biomaterial for the intended application of bio parts is important. The material should have high durability without immunological rejection in the human body's environment and a good response with tissue cells. The mechanical properties of the materials should concurrently match with human bone properties like density, tensile strength, fatigue resistance, hardness, and a low modulus of elasticity, elongation wear resistance and corrosion resistance. It is difficult to get all the feasible properties in one material. Corrosion is the disintegration of an implant alloy that will spoil the implant material and surrounding tissues. For this reason, a material with a greater corrosion resistance and high strength for biomedical applications is preferred. These materials have replaced some of the parts of the human body, shoulders, knee, hips, elbows, and oro-dental structure. ${ }^{3}$ Few materials are used in a very active role, like actuators, vascular stents, heart vertebras, orthodontic arch wires, etc. The authors reported that expedient materials for biomedical implants such as stainless steel AISI 316L, cobalt-based alloys, CoCrMo alloys, titanium alloys, TiNi shape-memory alloys and special alloys. $^{2}$

The materials that are used for surgical implants in biomedical are listed in Table $\mathbf{1}$. In addition, all these biomaterials posses a higher modulus of elasticity than the bone. Among these materials, the titanium-based material is feasible and most appropriate for implantation. Due to the combination of outstanding characteristics compared to other materials such as enhanced biocompatibility, low modulus, high strength and good osseointegration.

These materials are highly non-toxic and do not cause any allergic reaction with the human body. Ti6Al4V is the long-term main medical alloy for implantation. However, these alloys have a possible toxic effect on the body, caused by the vanadium and aluminium. Due to this reason, vanadium- and aluminium-free titanium alloys are preferred for implant applications. ${ }^{4}$ The surface properties of a metallic material play a role in the spontaneous build up of a stable and inert oxide layer to make it highly biocompatible. The responses induced by the material in the human body and degradation of the material are the two main factors in biocompatibility. Commercially pure $\mathrm{Ti}$ materials are preferred as they give bio-integration with the surrounding tissues, cells of the bone and healing, bone growth, etc. Material with a highly appropriate surface is required for the implant to assimilate with adjacent bone. Hence, surface engineering plays a major role in the development of good osseointegration. The success of a dental implant is highly dependent on the chemical, physical, mechanical and surface topography characteristics of the implants. Surface topography plays a vital role in osseointegration 
Table 1: Bio-material and their mechanical properties ${ }^{1,4}$

Tabela 1: Biomateriali in njihove mehanske lastnosti ${ }^{1,4}$

\begin{tabular}{|c|c|c|c|c|c|}
\hline Material & $\begin{array}{l}\text { Yield strength } \\
\text { (Mpa) }\end{array}$ & $\begin{array}{l}\text { Ultimate tensile } \\
\text { strength }(\mathrm{MPa})\end{array}$ & $\begin{array}{c}\text { Modulus } \\
(\mathrm{GPa})\end{array}$ & $\begin{array}{c}\text { Elongation } \\
(\%)\end{array}$ & $\begin{array}{c}\text { Density } \\
(\mathrm{g} / \mathrm{cc})\end{array}$ \\
\hline 316L steel & 290 & 580 & 210 & 50 & 7.99 \\
\hline CoCrMo & $275-1585$ & $600-1795$ & $200-230$ & 8 & 8.3 \\
\hline CoCrNiMo & 241 & 793 & 232 & 50 & 8.43 \\
\hline $\mathrm{TiNi}$ & $195-690$ & 895 & 80 & $25-50$ & 6.45 \\
\hline CP Ti grade I & 170 & 240 & 102 & 24 & 4.5 \\
\hline CP Ti grade II & 275 & 345 & 102 & 20 & 4.5 \\
\hline CP Ti grade III & 380 & 450 & 102 & 18 & 4.5 \\
\hline CP Ti grade IV & 483 & 550 & 104 & 15 & 4.5 \\
\hline Ti-6Al-4V-ELI & 795 & 860 & 113 & 10 & 4.4 \\
\hline Ti-6Al-4V & 860 & 930 & 113 & 10 & 4.4 \\
\hline Ti-6Al-7Nb & $880-950$ & $900-1050$ & 114 & $8-15$ & 4.4 \\
\hline Ti-5Al-2.5Fe & 895 & 1020 & 112 & 15 & 4.4 \\
\hline $\mathrm{Ti}-15 \mathrm{Zr}-4 \mathrm{Nb}-2 \mathrm{Ta}-0.2 \mathrm{Pd}$ & $693-806$ & $715-919$ & 94-99 & $18-28$ & 4.4 \\
\hline Ti-29Nb-13Ta-4.6Zr & 864 & 911 & 80 & 13.2 & 4.4 \\
\hline Ti-13Nb-13Zr & 900 & $973-1037$ & $19-84$ & 15 & 4.99 \\
\hline Ti-12Mo-6Zr-2Fe & $1000-1060$ & $1060-1100$ & $74-85$ & $18-22$ & 5.0 \\
\hline $\mathrm{Ti}-35 \mathrm{Nb}-7 \mathrm{Zr}-5 \mathrm{Ta}$ & $742-806$ & 596 & 55 & $11-22$ & 5.0 \\
\hline $\mathrm{Ti}-29 \mathrm{Nb}-13 \mathrm{Ta}-4.6 \mathrm{Zr}$ & 715 & 911 & 65 & 22 & 5.0 \\
\hline Ti-35Nb-5Ta-7Zr-0.4O & $590-1074$ & 1010 & 66 & $21-27$ & 5.0 \\
\hline Ti-15Mo-5Zr-3Al & 1475 & $724-900$ & 82 & 14 & 4.95 \\
\hline
\end{tabular}

and shorter healing time from implant placement to restoration. $^{2}$

\subsection{The reason for surface modification}

The biomedical applications of titanium alloys include replacement parts such as hip, knee, shoulder, screws, nuts, plates, nails, housing devises for pacemakers and artificial heart valves, surgical instruments and so on..$^{5-7}$ The goal of dentistry is to restore the normal function of a patient's speech, oral health and aesthetics, regardless of a weakened, diseased, or otherwise injured oral system. Although titanium alloys are extensively used in dental-implant manufacture, failure of the fixation may still occur because of insufficient early osseointegration, infection, surgical trauma, or premature overloading, improper surgical placement, fatigue and inadequate quality of the bone surrounding the implants. ${ }^{8}$ Successful dental implantation is highly dependent on the biochemical, physical, mechanical and surface topography characteristics of the implant surface. The biocompatibility of the material is important and needless to say it must be non-toxic and should not cause any allergic reaction with the human body. Ti6Al4V has been extensively used for implant manufacture, but concerns have been raised about their long-term effects because of their vanadium and aluminium content. Due to this reason, commercially pure titanium alloys are preferred for implant applications. ${ }^{4}$ The surface properties of metallic materials play a significant role in the spontaneous build up of a stable and inert oxide layer, which is usually highly biocompatible. The response induced by the implant material on the human body and the degradation thereof are the two main factors that contribute to biocompatibility. These commercially pure titanium alloys are preferred as they are bio-compatible with the surrounding tissue and bone cells and do not inhibit healing and bone growth. It does, however, also imply that a material with an appropriate surface is required for effective osseointegration with adjacent bone. Hence, surface engineering plays a significant role in the improvement of the implantation process. Surface topography has a significant effect on osseointegration and a shorter healing time from implant placement to restoration. ${ }^{2}$ Hence, many studies tried to optimize dental and orthopedic implants by the modification of surface chemistry and surface topography by using many methods such as sandblasting, acid etching, electrochemical machining and anodizing to improve the aesthetic appearance. ${ }^{9}$ However, the surface engineering of titanium improves the aesthetic appearance of the implant, the biocompatibility of the implant, the corrosion resistance, the fatigue life of the implant and to reduce the friction between the implant and abutments. The surface modification is also used to help osseointegration, a faster healing time, improved bone implantation contact and the life expectancy of titanium implants. Titanium dentures become dimmer, weakening its aesthetic aspect when being used for a long time in the oral environment. With the higher demand of dental implants not only for the restoration of oral function, such as chewing, pronunciation and durability, but also dental aesthetics, it is necessary to improve the titanium dental aesthetic for practical clinical uses.

The self-colouring of the anodisation of titanium has been patented ${ }^{1}$ and the anodisation improves the aesthe- 
tic appearance. The uniform colours of the interference pattern can be obtained for any large surface area. From the practical point of view the surface treatment leads to producing uniform colours. This surface treatment improves the aesthetic appearance in dental implant application and other industrial uses such as jewellery and architectural purposes. ${ }^{1}$ The surface treatment of titanium also improves the corrosion behaviour of the alloy. A. Karambakhsh et al. ${ }^{10}$ have studied the effect of anodisation on the corrosion behaviour of a commercially pure (CP) titanium alloy. Anodising in sulphuric acid greatly reduced the corrosion resistance of the samples, which is due to the formation of a resistant anodic film. The greater film thickness increased the corrosion resistance. The corrosion resistance of the implant needs to be good because specific metal ions released from the implant can induce inflammation reaction with the surrounding tissues. Moreover, in the long term, it may be harmful to the human body. The porous oxide films formed by the anodic spark deposition, the porous oxide, predominantly consist of the $\mathrm{TiO}_{2}$ phase. The crystalline structure of the film consists of anatase and rutile. The anodic oxidation improves the corrosion resistance of the $\mathrm{CP}$ titanium alloy. ${ }^{11}$

Titanium has excellent corrosion resistance, good fatigue strength and acceptable fracture toughness, but it has poor sliding characteristics. These alloys fail by galling and often exhibit high and unstable friction coefficients. To improve these properties, surface engineering techniques are required, such as hard coating, soft coating, diffusion treatment, and shot-peening. Diffusion treatments include oxygen diffusion, nitriding and carburizing. ${ }^{12}$ The surface modification of titanium is also necessary to prevent the release of toxic elements from titanium such as aluminium and vanadium, which are known to cause toxicity. ${ }^{13}$ Porous implants have an effect on the fatigue strength in a highly loaded application, such as the hip joint. These alloys experienced a drastic reduction in strength due to the porosity, and due to the stress intensity the pores are the major sources of weakness in the fatigue strength. To achieve a functionally strong implant, a porous implant design needs to account for these losses in metal strength. Hence, the surface engineering of these alloys is essential.

The bulk properties of biomaterials, such as non-toxicity, corrosion resistance or controlled degradability, modulus of elasticity, and fatigue strength have long been recognized as being highly relevant in terms of the selection of the right biomaterials for a specific biomedical application. The events after implantation include interactions between the biological environment and artificial material surfaces, the onset of biological reactions, as well as the particular response paths chosen by the body. The material surface plays an extremely important role in the response of the biological environment to artificial medical devices. In implants made of titanium, the normal manufacturing steps usually lead to an oxidized, contaminated surface layer that is often stressed and plastically deformed, non-uniform and rather poorly defined. Such native surfaces are clearly not appropriate for biomedical applications and some surface treatment must be performed. Another important reason for conducting surface a modification of titanium medical devices is that specific surface properties that are different from those in the bulk are often required. For example, in order to accomplish biological integration, it is necessary to have good bone formability. In blood-contacting devices, such as artificial heart valves, blood compatibility is crucial. In other applications, good wear and corrosion resistance are also required. The proper surface modification techniques not only retain the excellent bulk attributes of titanium and its alloys, such as a relatively low modulus, good fatigue strength, formability and machinability, but also improve specific surface properties required by different clinical applications. According to the different clinical needs, various surface modification schemes have been proposed and are shown in Table 2.

In the following sections, the surface modification of titanium implants to improve the bioactivity, biocom-

Table 2: Summary of surface-modification methods for titanium implants ${ }^{15}$

Tabela 2: Pregled metod za modifikacijo površine titanovih vsadkov ${ }^{15}$

\begin{tabular}{|l|l|l|}
\hline \multicolumn{1}{|c|}{ Surface modification methods } & \multicolumn{1}{|c|}{ Modified layer } & \multicolumn{1}{c|}{ Objectives } \\
\hline $\begin{array}{l}\text { Mechanical methods: } \\
\text { machining, grinding, polishing, blasting }\end{array}$ & $\begin{array}{l}\text { Rough or smooth surface formed by } \\
\text { subtraction process }\end{array}$ & $\begin{array}{l}\text { Produce specific surface topographies; } \\
\text { clean and roughen surface; improve } \\
\text { adhesive in bonding }\end{array}$ \\
\hline $\begin{array}{l}\text { Chemical methods } \\
\text { acid treatment }\end{array}$ & $<10 \mathrm{~nm}$ of surface oxide layer & Remove oxide scales and contamination \\
\hline Alkaline treatment & $\sim 1 \mu \mathrm{m}$ sodium titanate gel & $\begin{array}{l}\text { Improve biocompatibility, bioactivity or } \\
\text { bone conductivity }\end{array}$ \\
\hline Hydrogen peroxide treatment & $\begin{array}{l}\sim 5 \mathrm{~nm} \text { of dense inner oxide and porous } \\
\text { outer layer }\end{array}$ & $\begin{array}{l}\text { Improve biocompatibility, bioactivity or } \\
\text { bone conductivity }\end{array}$ \\
\hline Sol-gel & $\begin{array}{l}\sim 10 \mathrm{~nm} \text { of thin film, such as calcium } \\
\text { phosphate, TiO }{ }_{2} \text { and silica } \\
\text { incorporation of electrolyte anions }\end{array}$ & $\begin{array}{l}\text { Improve biocompatibility, bioactivity or } \\
\text { bone conductivity }\end{array}$ \\
\hline Anodic oxidation & $\begin{array}{l}\text { induce specific surface topographies; } \\
\text { improved corrosion resistance; improve } \\
\text { biocompatibility, bioactivity or bone } \\
\text { conductivity }\end{array}$ \\
\hline
\end{tabular}


patibility, wear and corrosion resistance by the various surface modification technologies are discussed. These methods are classified into mechanical, electrochemical and hybrid processes according to the formation mechanism of the modified layer on the material surface.

\section{ABRASIVE BLASTING}

Abrasive blasting is one of the mechanical surface modification methods involving plastic treatment, shaping or the removal of materials from the surface. The objective of this mechanical modification process is to obtain a surface roughness, topography, removal of surface contamination and improve its surface-adhesion properties. The surface of titanium is abrasively sand blasted with hard ceramic particles to increase the surface roughness. Depending on the particle size to which the surface roughness can be produced, the surface roughness depends on the bulk material properties, ceramic particle material, particle size, particle shape, particle impact speed and the density of the particles. The surface may consist of craters, ridges and particles embedded on the surface. The surface roughness increases with an increase in ceramic particles of size 25 $\mu \mathrm{m}$ to $250 \mu \mathrm{m}$ of $\mathrm{TiO}_{2}$ or $\mathrm{Al}_{2} \mathrm{O}_{3}$. The blasted surface with
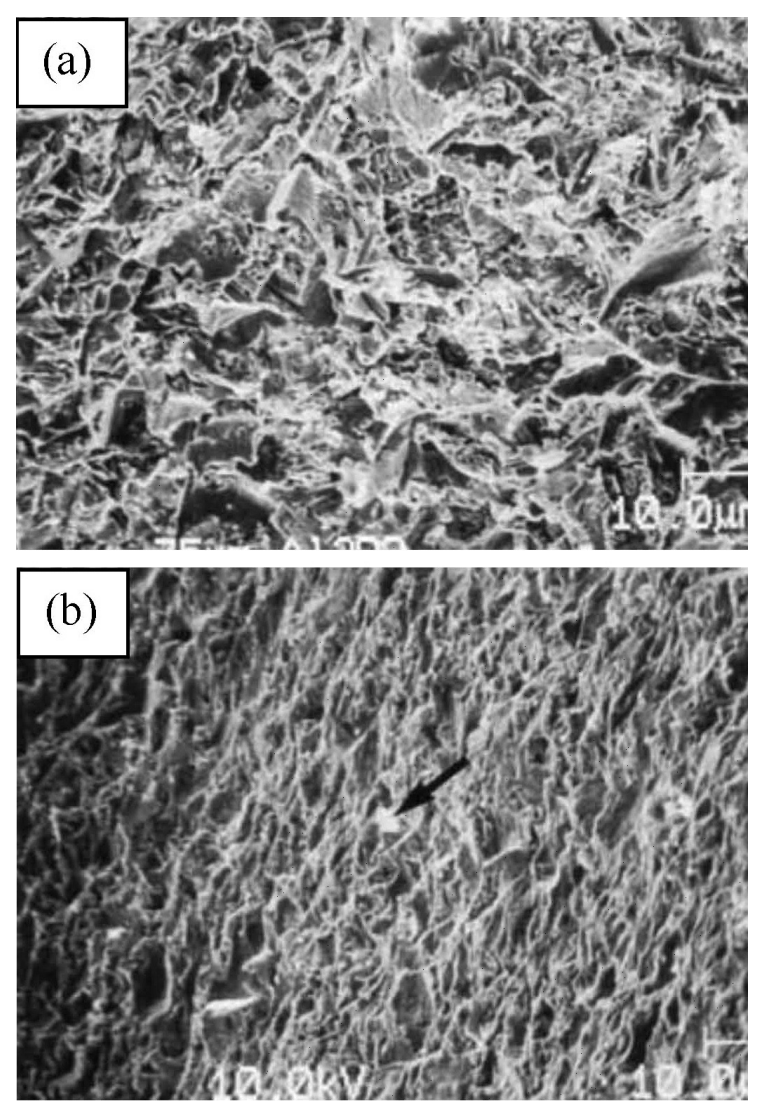

Figure 1: Sand-blasted titanium surface with different particle sizes: a) $25 \mu \mathrm{m}$ and b) $75 \mu \mathrm{m}^{16}$

Slika 1: Površina titana, obdelana s peskanjem z delci različne velikosti: a) $25 \mu \mathrm{m}$ in b) $75 \mu \mathrm{m}^{16}$ a particle size of $25 \mu \mathrm{m}$ has a higher surface roughness compared to machined surfaces, but smoother than 75 $\mu \mathrm{m}$ and $250 \mu \mathrm{m}$ particles on blasted surfaces. ${ }^{14}$ The authors also made comparisons between different particle sizes $(25 \mu \mathrm{m}$ and $75 \mu \mathrm{m})$ of $\mathrm{Al}_{2} \mathrm{O}_{3}$ blasted on the surface of titanium implants on the torque and surface topography. They concluded that more torque is required to remove an implant with the surface blasted with $75 \mu \mathrm{m}$ $\mathrm{Al}_{2} \mathrm{O}_{3}$ particles compared to $25 \mu \mathrm{m}$ particles. It is observed that the surface was blasted by different particle sizes, such as $25 \mu \mathrm{m}$ and $75 \mu \mathrm{m}$ of $\mathrm{Al}_{2} \mathrm{O}_{3}$. It was characterized that two surfaces having different irregularities and different degrees of surface roughness have a greater surface roughness when blasted with a particle size of 75 $\mu \mathrm{m}(\mathrm{Sa}-1.45 \mu \mathrm{m})$ compared to a surface blasted with 25 $\mu \mathrm{m}(\mathrm{Sa}-1.11 \mu \mathrm{m})$, as shown in Figure 1. Titanium oxide particles can be used for the grit blasting of dental implants, which produces an average surface roughness of $1 \mu \mathrm{m}$ to $2 \mu \mathrm{m}$. Many researchers reported that the torque force increases with surface roughness. ${ }^{14,15}$ This indicates an improvement in the biocompatibility, cell activity and osseointegration of the titanium implant using the sandblasting method. The roughening of implants by titanium plasma spraying used to produce a rough surface of the implant can be obtained by a process known as grit blasting, which makes use of hard ceramic particles. The hard particle collides with the surface of the implant at a high velocity using compressed air. Different surface roughness can be obtained from the size of the ceramic particle and the type of particle. After blasting with a ceramic particle, cleaning the surface of the titanium is very important due to some of the residues of the alumina being embedded on the surface of the implant. The alumina ceramic particle is insoluble in acid. This does not, however, completely remove the osseointegration difficulties of the implant. A residue of particles may react with the surrounding tissue cells and cause failure in the implant fixation. The blasted surface has greater bone implant contact (BIC) compared to a machined implant. Titanium oxide particles can also be used for blasting the implant, which shows an improvement in the BIC compared to a machined surface. ${ }^{16}$ The experimental demonstration of A. Abron et al. ${ }^{17}$, shows a higher bone implant contact in the blasted surface implants compared to machined surface implants. These studies confirm that roughening of the titanium dental implants increases their mechanical fixation to the bone, but not their biological fixation. ${ }^{18-20}$ A. Karacs et al. ${ }^{21}$ investigated the morphology of machined, blasted and laser-treated surfaces of titanium. The $\mathrm{Al}_{2} \mathrm{O}_{3}$ blasted surface has a unique surface morphological characteristic that enhances the osseointegration process. Research conducted on animals indicates a $50 \%$ improvement in the removal torque of an implant can be expected. The aforementioned indicates that the sand-blasting 
preparation method is a promising technique for preparing titanium dental implant surfaces.

\section{ELECTROCHEMICAL PROCESS}

An electrochemical process of surface modification includes electro polishing, anodic oxidation, acid etching and electrochemical machining. Electro polishing is a controlled electrochemical dissolution of the surface. The process was carried out to obtain a mirror-like smooth surface finish that removes plastically deformed amorphous surface layer residues due to machining. ${ }^{22}$

\subsection{Anodizing}

Anodizing is an electrolytic chemical oxidation process whereby the oxide layer thickness is engineered to the aesthetic appearance (colour) of the titanium. A thin passive oxide layer is formed, which is usually more stable and thicker than the natural oxide layer that is formed when it first made contact with the air. Anodic titanium oxide has been used in various fields of advanced technologies and industries, e.g., an electrical component, resistive material for friction and wear, decorative coating, resistance to corrosion, as a reflective material and recently as photo electrode material and as well as to improve the aesthetic appearance of implants. ${ }^{17,23}$ The anodic oxidation of the titanium surface for implant applications is relatively inexpensive and may produce a uniform thickness throughout the surface area. $^{24}$ The anodic oxidation is a simple and novel method for colouring titanium to improve the aesthetic appeal due to the high reactivity of titanium with oxygen. The anodization of titanium has been patented. ${ }^{1}$

Anodization is a surface-modification technique that has been proposed to minimize the rate of ion release from titanium alloys. There is an alternative method to produce surface modification that includes ion implantation, chemical passivation, and plasma spraying. All the common methods used to perform surface modifications lack the required layer thickness. However, the plasma spraying method can produce a thick coating of oxide layer. but is a difficult method for generating a uniform layer on the surface when applied to porous and non-regular substrates. ${ }^{25}$

Anodizing is an electrochemical oxidation process of thickening the oxide layer on the surface of titanium metals. Electrochemical anodizing is the most common method to control the colouring of titanium. ${ }^{26}$ This process is a surface-modification process that is efficient in forming an uniform and stable oxide layer on the implant surface compared to other surface-modification processes. e.g., electrochemical, ion implantation and heat treatment, etc. ${ }^{27}$ Titanium anodizing improves the surface properties which increases the lubricity, anti-galling and fatigue properties of the alloy. Because of the aforementioned properties, anodizing is becoming rapidly popular in treating components used in the medical industry, especially on orthopaedic implants. This process endows with an extensive formation of oxide coating under controlled conditions to offer the desired result. Due to this, it is biocompatible and nontoxic, resulting in a drastic improvement in performance purposes used for biomedical dental implants. The anodizing process will be carried out with either constant current (Galvonostat) or constant voltage (Potentiostat). Among the other surface-modification processes, the anodic oxidation process is easy to deposit the oxide film on the titanium surface by means of an electrochemical process. This process has various controlled variables such as the type of electrolyte used, the voltage applied across the electrodes and the current used for the process. A change in any of these variables can affect the surface morphology, chemical composition and film thickness of the titanium implant. ${ }^{28}$ The thick oxide film formed during anodic oxidation at higher applied voltages leads to a high surface roughness, which provides a high bonding strength between the oxide and the titanium substrate. Moreover, the surface hardness is improved near the oxide layer due to anodic oxidation, which is caused by the incorporation of the oxide into the titanium alloy. ${ }^{29,30}$ It is reported that the bioactivity of titanium can be improved by oxide film formation on the titanium surface by anodic oxidation. This oxide layer is either anatase or a mixture of anatase and the rutile crystal structure. Many researchers have reported that the bioactivity of titanium can be improved by varying the thickness of the oxide layer and the crystal structure. The anodization takes place in either galvanostatic or potentiostatic conditions with an increase in the voltage or current density leading to an increase in the oxide layer thickness. The manipulation of the oxide layer also affects the crystalline structure surface of the implant. The anodic oxidation process creates a porous surface structure on the titanium surface as shown in Figure 2. Figure 2 shows how the oxidized dental implant morphology has volcano-shaped saliencies as the oxide form on the surface as a function of the anodic voltage,

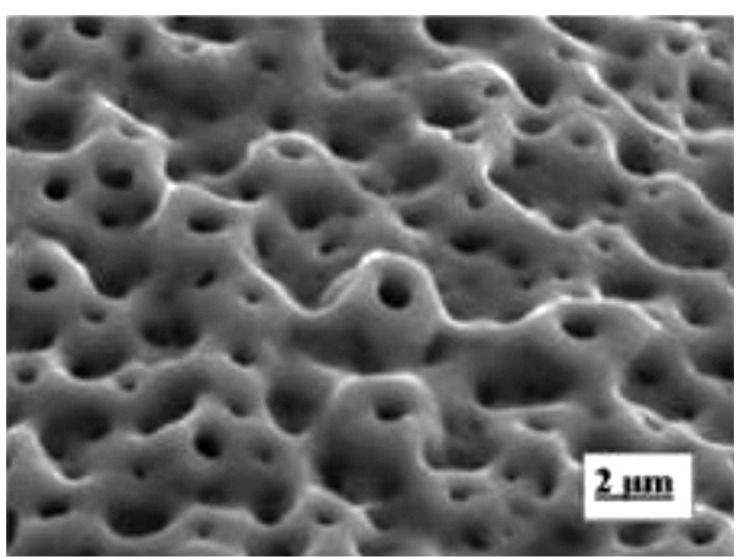

Figure 2: Anodized dental implant surface, resembling small volcanoes ${ }^{34}$

Slika 2: Anodizirana površina vsadka, podobna majhnim vulkanom ${ }^{34}$ 
current, concentration of electrolyte and a change in the temperature. The titanium oxide $\left(\mathrm{TiO}_{\mathrm{X}}\right)$, where $(1<\mathrm{X}<2)$ in the general form, depending on the $\mathrm{X}$ values 5 crystalline oxides are formed such as cubic (TiO, $a_{\mathrm{o}}=0.424$ $\mathrm{nm})$, hexagonal $\left(\mathrm{Ti}_{2} \mathrm{O}_{3}, a_{o}=0.537 \mathrm{~nm}\right)$, tetragonal $\left(\mathrm{TiO}_{2}\right.$, Anatase, $a_{0}=0.378 \mathrm{~nm}$, rutile, $\left.a_{0}=0.458 \mathrm{~nm}\right)$, and orthorhombic (Brookite, $a_{\mathrm{o}}=0.917 \mathrm{~nm}$ ). There are also nonstoichiometric oxides and amorphous oxides. It is commonly understood that among these oxides, only the rutile and anatase phases are stable under normal conditions. The rutile and anatase oxide layer has different physical properties in terms of surface tension, the rutile condition is hydrophobic, and the anatase condition is hydrophilic. These oxide layers are the most important structure for the osseointegration of implants. K. Kim et al. ${ }^{31}$ studied the surface properties and biological responses of anodized samples. The anodized surface has a porous and thick oxide layer of $\mathrm{TiO}_{2}$. This exhibits better corrosion resistance and shows a significantly lower water contact angle compared to machined surfaces. The anodized surface showed enhanced alkaline phosphate activity compared to machined surfaces. The higher hydrophilic property and wettability is generally favourable for biocompatibility. Increased wettability promoted the interaction between the impact surface and biological environment. Cell activation was more rapid on hydrophilic surfaces. The hydrophilic surface promotes the adhesion of the relevant proteins.

The anodized implant surfaces were characterized by $\mathrm{X}$-ray diffraction, as shown in Figure 3. ${ }^{32}$ It indicates that the predominant anatase phase exists on the anodized surface. When compared with the machined, sandblasted and acid-etched surface, the main oxide layer is rutile. With respect to surface morphology, hydrophobicity was observed in the machined surface, but the SLA and acid etched had different surface morphologies. The anodized implant has volcano-like surface porous structures, having both rutile and anatase on the surface, as shown in Figure 3. The tissue healing process and bone growth is quick on the anodized and acidetched implant surfaces compared to machined implants. B. C. de V. Gurgel et al. ${ }^{33}$ studied the efficiency of

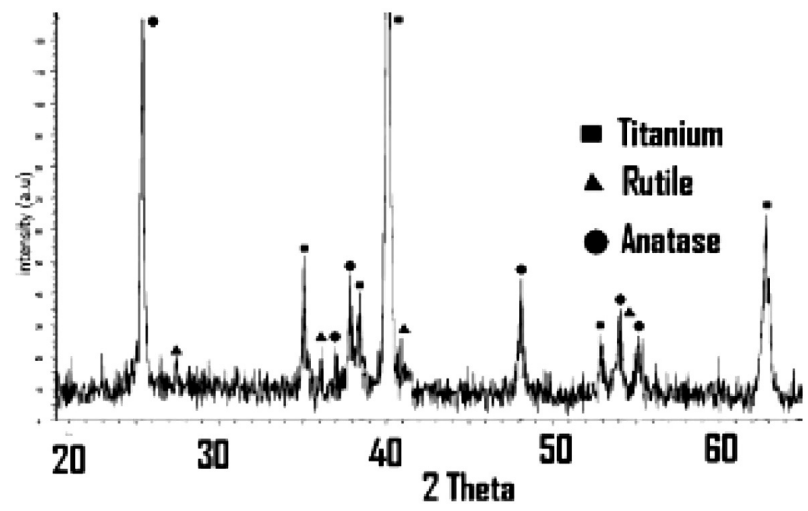

Figure 3: XRD pattern of anodized sample ${ }^{33}$ Slika 3: Rentgenogram (XRD) anodiziranega vzorca ${ }^{33}$ anodized implants on animals. Dogs were used to perform implant testing. After 3 months the initial trauma, each wound was inspected and defects were observed, which measured $5 \mathrm{~mm}$ in height and $4 \mathrm{~mm}$ in width. Anodized implants were planted inside the root canal of the wound and were allowed to heal for an additional 3 months. The percentages of bone-to-implant contact and the bone density of the anodized implants were observed to be $57.03 \pm 21.86 \%$ and $40.86 \pm 22.73 \%$, whereas the machined implants were $37.39 \pm 23.33 \%$ and $3.52 \pm 4.87 \%$, respectively. Burgos et al. ${ }^{34}$ also conducted experiments on rabbits. They observed an osseointegration rate for the anodized implants of $20 \%$ (after $7 \mathrm{~d}$ ), $23 \%(14 \mathrm{~d})$ and $46 \%(28 \mathrm{~d})$, compared to $15 \%$ (in $7 \mathrm{~d}$ ), $11 \%(14 \mathrm{~d})$, and $26 \%$ (28 d) for the machined surface.

Despite titanium's biological compatibility, it is considered to be an inorganic material. This means that the metal does not form part of the human body. It has some properties that may require modifications to improve its integration into the jawbone, patient comfort, satisfaction and confidence. The potential problem in clinical application is that titanium dentures become dim, which impairs its aesthetic appearance after a long period of time. There is a higher demand for implant prostheses. This is not only for oral functions such as mastication, pronunciation and durability, but also dental aesthetics is also important. Several patients who have received titanium dental implants have complained about the decay of its aesthetic appearance. In most cases the gum covering the implant is thick enough to prevent implant visibility. But since implants have been used to replace or insert teeth, it was found that not all patients have the same gum thickness. Several cases have been reported where the dark metallic colour of titanium shown through the patient's gums. In cases where dissatisfaction was present of its aesthetic appeal, colour appearance was changed by an electrochemical anodic oxidation process which produces the interference of colours.

Titanium has an iron-dark appearance and is visible when it becomes exposed. In other cases the patient has thin gums and the titanium would appear beneath the skin. Many alternative measures have been sought ought to improve on its aesthetics. Some materials have been developed to replace titanium. Dentists would also use techniques to veneer the titanium with a white material or graft tissue over the visible part. However, mechanical methods are unmanageable, inexact and form contaminant particles on the titanium implant surfaces. Similarly, acid etching has no ability produce controllable surface topographies and it has the potential to form residual surface acids, which is harmful to bone growth. Implant surfaces formed through this process are nonuniform on the microscale or macroscale. However, osteoblast may accustom to a nanoscale topology rather than a microscale environment. As a result, more desirable methods to modify Ti surfaces are needed to promote tissue cells 
and bone growth. ${ }^{35-37}$ The surface integrity of the Ti6Al4V alloy was studied by applying different surface treatment processes. The study focused on pickling and anodization. ${ }^{38}$ An investigation of these processing techniques revealed no significant changes in the microstructure of the implant and surface oxygen and hydrogen superficial content were found to be unchanged. The roughness characteristics remained mostly unchanged. This surface-treatment technique revealed that compressive residual stresses significantly decreased and that internal stresses were mainly located on the oxide interface. Moreover, the fatigue resistance decreased after the application of either pickling or anodization on the Ti64 alloy. The effect of anodization time on the surface morphology, surface roughness, and crystal structure was studied by $\mathrm{L}$. Wu et al. ${ }^{39}$ The surface roughness increased with anodization time up to $20 \mathrm{~min}$, and later dropped down, which is due to localized rapture of the compact inner layer and nucleation of the secondary oxide particles. The uniformity of the surface and the relative intensity of the anatase and rutile tended to increase with longer anodization times. Y. T. Sul ${ }^{40}$ studied the electrochemical growth behaviour and surface behaviour of $\mathrm{TiO}_{2}$ nanotubes fabricated on $\mathrm{TiO}_{2}$ grit-blasted screw-shaped rough titanium implants. The potentiostatic anodization of blasted screw-shaped implants at $20 \mathrm{~V}$ in $1-\mathrm{M} \mathrm{H}_{3} \mathrm{PO}_{4}+0.4 \%$ of mass fractions $\mathrm{HF}$ for $30 \mathrm{~min}, 1 \mathrm{~h}$ and $3 \mathrm{~h}$ resulted in highly nanopore structures and vertical aligned nanotubes. The surface roughness value decreased with the reaction time and the results of the animal study provided significant evidence that the nature of nanotubes have superior bone responses compared to blasted implants. This indicates that $\mathrm{TiO}_{2}$ nanotubes have the potential to be used in the field of bone implant and bone tissue engineering.

\subsection{Acid etching}

Acid etching is a chemical process used to modify the surface of titanium implants. It increases the retention between the implant surface and the bone by enhancing the surface properties of the implant such as osteoblast activity and quick bone growth. Strong acids used for acid etching include $\mathrm{H}_{2} \mathrm{SO}_{4}, \mathrm{HNO}_{3}, \mathrm{HCl}$ and hydrofluoric acid. These acids produce micro pits on the titanium implant surface, as shown in Figure 4. The acid-etching process has been used to promote the osseointegration process beyond 3 years. There is no need to use any external reagents that contaminates the implant surface. The biological response of this surface in terms of bone apposition and bone-implant contact ratio is comparatively high. Compared to the machined surfaces, acid-etched surfaces have a higher bone implant contact. ${ }^{16}$ A significantly higher torque is required to remove the acid-etched samples compared to the machined implants, but a lower torque compared to plasma-sprayed implants. The disadvantage of acid etching is that it reduces the mechanical properties of titanium implants, which is caused by hydrogen embrittlement. The presence of micro cracks is also observed on the surface of the implants, leading to a reduction in fatigue resistance. This hydrogen embrittlement forms the brittle phase in the titanium, leading to a reduction in ductility. The reduction in ductility leads to the occurrence of fracture in implants. ${ }^{41}$ The influence of the implant surface on the primary stability is imperative. ${ }^{42}$ The surface topography and roughness positively influences the healing process of the bone by favouring the cellular response and cell-surface interaction. Rough surfaces are considered to enhance the primary stability and allow firm mechanical fixation to the surrounding tissues. ${ }^{43}$ Figure 5 shows the primary stability of dental implants due to different surfacefinishing techniques. The surface treatment process significantly alters the surface-roughness parameters, leading to a change in the cell-surface interaction, as indicated in Figure 5. The anodized surface $\left(R_{\mathrm{a}}-1.11 \mu \mathrm{m}\right)$ has a greater surface roughness compared to the machined surface $\left(R_{\mathrm{a}}-0.74 \mu \mathrm{m}\right)$ and acid etched surface $\left(R_{\mathrm{a}}-0.91 \mu \mathrm{m}\right)$, which supports the healing process. It is clear that the improved surface roughness of the

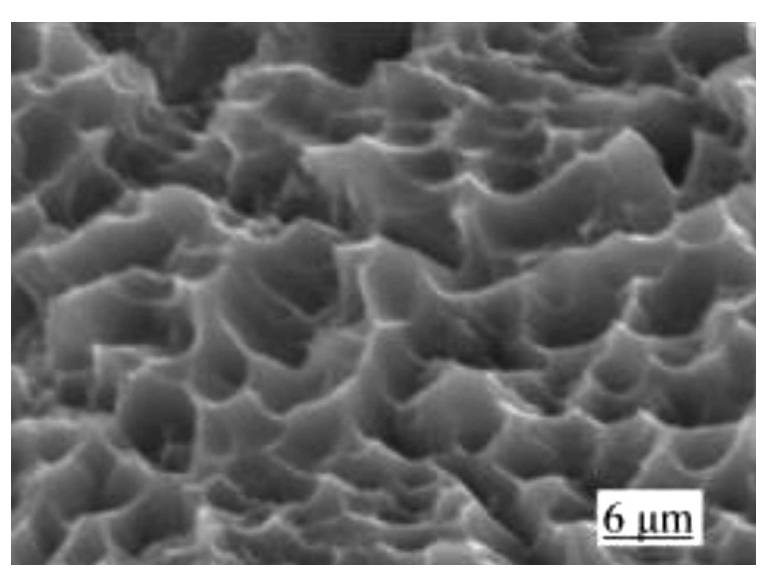

Figure 4: Acid etched surface of titanium ${ }^{35}$

Slika 4: $\mathrm{S}$ kislino jedkana površina titana ${ }^{35}$

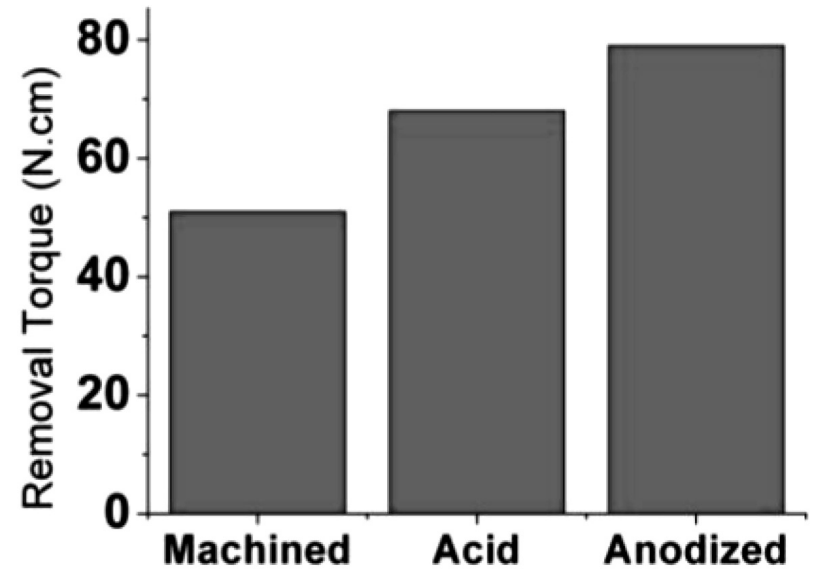

Figure 5: Effect of surface treatment on torque removal ${ }^{34}$ Slika 5: Vpliv obdelave površine na moment pri odstranitvi ${ }^{34}$ 
acid-etched surfaces has a positive effect on removal torque compared to machined samples. The anodized sample has remarkable improvement in the torque removal force over the machined and acid etched. The average surface roughness is highest for anodized samples, compared to other surface-treatment techniques.

M. V. D. Santos et al. ${ }^{43}$ studied the implant surface finish and geometry on the primary stability of dental implants. Their results showed that the maximum torque insertion depends on the coefficient of friction between the implant surface and the placement of the wall, the implant design thread geometry and the surface-treatment technique. It was also found that the insertion torque varies as the geometry of the implants varies. As seen from Figure 6, the torque insertion is higher in a conical geometry compared to a cylindrical implant. This is due to the different thread geometries. The surface area of contact with host tissues is increased in a conical implant. As the surface area increases, the friction between the implant surface and the bone wall increases, leading to a higher insertion torque. The implants of the anodized surface have a higher roughness and a larger coefficient of friction than the machined one. They reported that the rough surface has greater significant success rates compared to the smoother surface implants. The surface treatment improves the primary stability of the implants. The anodized implants have a higher primary stability compared to the acid-etched and machined implants. ${ }^{44}$

\section{HYBRID PROCESS}

\subsection{Sand blasted and acid etched (SLA)}

This consists of dual processes to obtain both the surface roughness, as well as the removal of particles from the implant surface. Sand blasting is beneficial for removing the surface contaminants, roughening surfaces to increase effective surface area and can produce beneficial compressive residual stresses. The acid

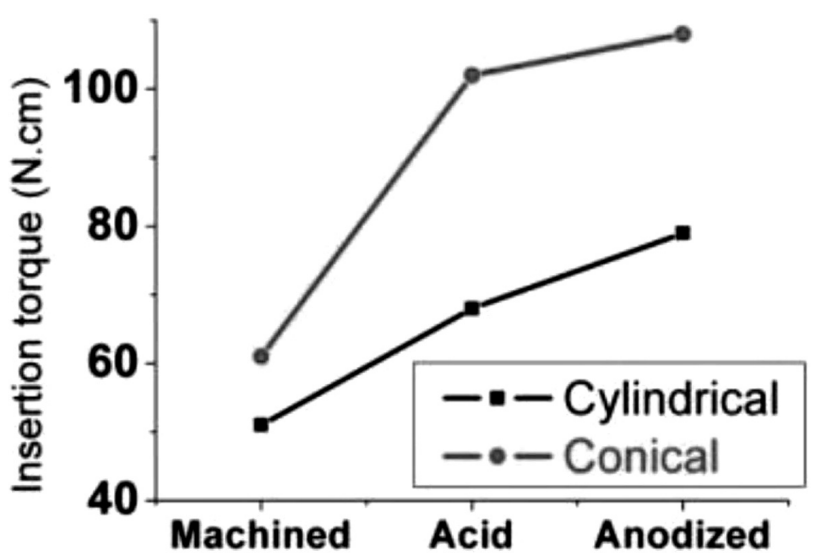

Figure 6: Effect of implant design and surface treatment on torque insertion $^{46}$

Slika 6: Vpliv zgradbe vsadka in obdelave površine na moment pri obdelavi ${ }^{46}$ etching chemical process changes the surface structure and leads to the creation of a hydride layer thickness of 1-2 $\mu \mathrm{m}$ on the intermediate oxide layer and implant surface. Titanium implants are blasted with ceramic particles and then subsequently etched by acids. In the sand-blasting process, peaks and craters/pits are more commonly found. These peaks and pits can be reduced by acid etching and small pits will be formed, which reduces the surface roughness. ${ }^{45}$ The different etching processes may also form the hydrides on the surface and the replacement of oxygen by the titanium hydrides, resulting in a slow transformation of the implant surface. This results in a nano-meter surface roughness, and helps in protein adhesion immediately after the implant is placed in the human body. ${ }^{46}$ SLA increases the bone formation and amount of growth. The dual modified implants have improved torque removal force compared to the single modified process, like acid etching, machined and plasma sprayed surface. ${ }^{47}$ Several studies have shown that SLA active implants have a better bone-contact ratio, stability and this reduces the healing time duration. J. K. Lee ${ }^{9}$ has studied the bone implant contact ratio (BIC) of modified surfaces in titanium implants. In an vivo study of dental implants they were classified into machined surface implants, sand blasted with large grit sizes and acid etched (SLA) surface implants, $\mathrm{TiO}_{2}$ nano tube array surface implants and $\mathrm{TiO}_{2}$ nano tube surface implants with rhBMP-2. Histomorphometric analysis studies were performed and the

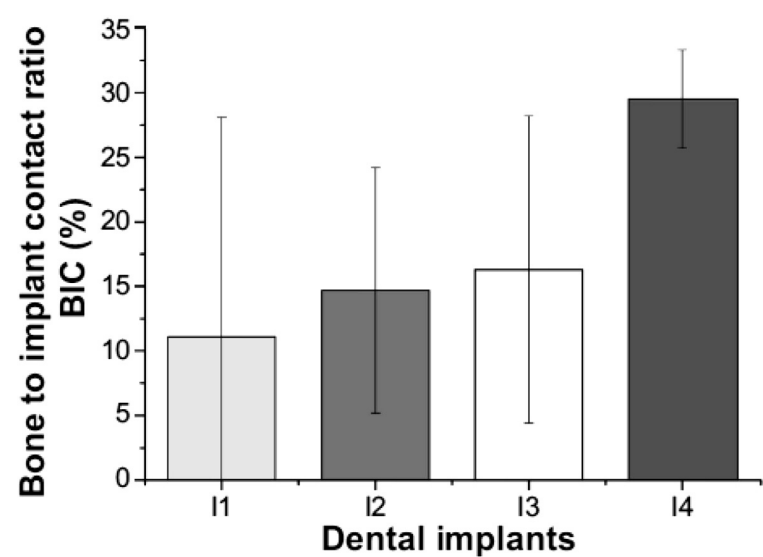

Figure 7: Bone-to-implant contact ratios of machined surface, SLA surface, $\mathrm{TiO}_{2}$ nanotube array surface, and $\mathrm{TiO}_{2}$ nanotube array surface with rhBMP-2, $\left(\mathrm{I}_{1}\right)$ machined surface implants, $\left(\mathrm{I}_{2}\right)$ SLA surface implants, $\left(\mathrm{I}_{3}\right) \mathrm{TiO}_{2}$ nanotube array surface implants, and $\left(\mathrm{I}_{4}\right) \mathrm{TiO}_{2}$ nanotube array surface implant with rhBMP-2

Abbreviations: BIC - bone-to-implant contact ratio, SLA - sandblasted large-grit and acid-etched, rhBMP-2 - recombinant human bone morphogenetic protein- $2^{9}$

Slika 7: Razmerje stika kost-vsadek pri strojno obdelani površini, SLA-površina, $\mathrm{TiO}_{2}$ matrika površine $\mathrm{z}$ nanocevkami in $\mathrm{TiO}_{2}$ matrika površine $\mathrm{z}$ nanocevkami $\mathrm{z}$ rhBMP-2; $\left(\mathrm{I}_{1}\right)$ strojno obdelana površina vsadka, $\left(\mathrm{I}_{2}\right)$ SLA-površina vsadka, $\left(\mathrm{I}_{3}\right) \mathrm{TiO}_{2}$ matrika površine vsadka $\mathrm{z}$ nano cevkami in $\left(\mathrm{I}_{4}\right) \mathrm{TiO}_{2}$ matrika površine vsadka $\mathrm{z}$ nanocevkami in $\mathrm{Z}$ rhBMP-2

Okrajšave: BIC - razmerje stika kost-vsadek, SLA - peskano z debelim peskom in jedkano s kislino, rhBMP-2 - rekombinantni morfogeni protein-2 človeške kosti $^{9}$ 
highest BIC of $29.5 \%$ was obtained $\mathrm{I}_{4}$ followed by $\mathrm{I}_{3}$ $(16.3 \%), \mathrm{I}_{2}(14.7 \%)$ and $\mathrm{I}_{1}(11.1 \%)$ groups, as shown in Figure 7. The bone-volume ratio was also measured around the implant threads, which was found to be highest in the $\mathrm{I}_{4}$ group $(77.3 \%)$ followed by $\mathrm{I}_{3}, \mathrm{I}_{2}$ and $\mathrm{I}_{1}$ groups $(67.2 \%, 53.7 \%$, and $66.9 \%$ respectively). The authors suggest that the nano tube array surfaces have improved osseointegration properties compared to machined and SLA-implant surfaces. $\mathrm{TiO}_{2}$ nano tube implant surfaces have an enhanced bone formation, bone strength and cell adhesion compared to other modified surfaces.

\subsection{Electro polished and anodized implants}

The bone response in the early healing period and the bone responses to different types of titanium surfaces were studied. The responses of different surfaces were analysed; the electro polished implant surface has a low degree of bone-to-implant contact compared to the machined implant surface after 1 week. After 3 weeks post-implantation there were no major differences between the machined, machined plus anodized, electro polished and electro polished and anodized implant surfaces, as can be seen in Figure 8. As observed from Figure 8, after 6 weeks the electro polished implant surfaces had less bone contact compared to the other three groups. The electro polished plus anodized implant shows higher bone implant contact, but has less BIC in comparison to the machined and machined plus anodized surfaces. The reason is that the electro polishing removes a significant amount of material from the surface, which decreased the diameter of the implant. The reduction in diameter of implants caused a lower BIC ratio during the initial healing. After 6 weeks, the electro polished surfaces had less bone contact, which may be due to a slower rate of mineralization around the surfaces. This is because the electro polished surface is smooth and the amount of bone attachment to the implant is less compared to the machined implants. The bone response

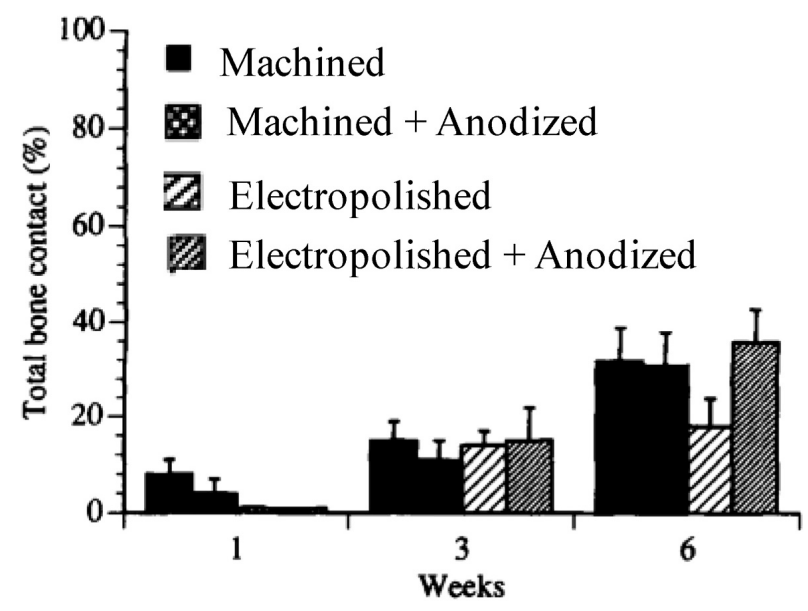

Figure 8: Total bone contact (\%): after 1 week, 3 weeks and 6 weeks ${ }^{51}$ Slika 8: Celoten stik s kostjo (\%): po 1 tednu, 3 tednih in 6 tednih $^{51}$ depends on two different types of surface roughness; the smooth surface expresses a lower degree of bone formation compared to the rough surface finish. The degree of a rough surface is adequate to furnish an overall response of the bone. However, the thick oxide on the bone formation was not practical when compared to two groups of machined implants. Thus, it seems that a combination of surface topography and thick oxide present on the electro polished plus anodized implant surfaces are the most encouraging type of surface roughness for bone growth and the rapid healing of interfacial tissues. ${ }^{48}$

\section{LASER MODIFICATION}

Laser is an emerging field in the manufacturing micro-components of complex surfaces of micro and nano levels. Laser surface engineering is advanced enough to modify the surface. This method becomes more popular method for resolving peri-implantitis. This technology claims a noncontact, no media and contamination-free method. The laser modification technique is very suitable for selective modification of surfaces and allows the generation of complex microstructures, this technique makes important in geometrically complex biomedical implants. The laser micromachining changes the micro and nano structured surface roughness of implant threads. The inner part of thread is more important than the outer part for bone formation and growth. The laser technique has advantage to treat only the inner part of the thread and leave the outer part machined. The pulsed laser melting of the titanium implant surface in a vacuum chamber is one of the surface-modification processes. The laser-treated surface morphology consists of more or less periodic wavelength of peaks with $50-100 \mu \mathrm{m}$ between the elements. ${ }^{16}$

S. Cho et al. ${ }^{49}$ studied laser treated, commercially pure titanium screws and inserted in right tibia metaphysics of white rabbits for 8 weeks. It was reported that the SEM of laser treated implants demonstrated a deep and regular honeycomb pattern with small pores and the removal torque was $23.58 \mathrm{~N}-\mathrm{cm}$ for the controlled machined implants and $62.58 \mathrm{~N}-\mathrm{cm}$ for the lasertreated implants. A. Gaggl et al. ${ }^{50}$ made an comparative study on four different dental implant surfaces treated with machined roughness, titanium spray coating, treated by aluminium oxide and treated by laser. It is reported that the laser-treated surface has high purity and showed enough surface roughness for good osteointegration and had a regular pattern of micro pores with an interval of $10-12 \mu \mathrm{m}$, a diameter of $25 \mu \mathrm{m}$ and a depth of $20 \mu \mathrm{m}$. Gill et al. ${ }^{51}$ studied the influence of laser surface modifications on the mechanical and electrochemical behaviour of $\mathrm{Ti}$ and Ti6Al4V implants. When laser modification was carried out for each metal, the microstructural changes were observed:

a) melting zone with small grain size and martensitic structures in aforementioned metal and 
b) the heat-affected zone (HAZ) with $\alpha$-phase in $\mathrm{CP}$ Ti with a higher grain size and Widmanstatten structure in Ti6Al4V.

Positive tensile residual stress was determined by means of X-ray analysis in the zones marked by laser. Furthermore, corrosion behaviour was studied in a simulated body fluid at $37{ }^{\circ} \mathrm{C}$. It was found that pitting was observed in different zones near the HAZ, and results showed that the corrosion resistance decreased in the laser-treated samples, and residual stresses and the martensitic microstructures favoured the decrease of the corrosion-fatigue life by around $20 \%$ in both metals under physiological conditions. G. Romanos et al. ${ }^{52}$ studied the osteoblast attachment on titanium surfaces after laser irradiation. It is reported that osteoblasts could be grown in all of the surfaces. The cell density is higher in the laser-irradiated surface than in the non-irradiated specimens because of the cleaner effect on superficial layer by the lasers. The laser irradiation on the titanium surface may promote the osteoblast attachment and further bone formation. Palmquist et al. $^{53}$ made an in-vivo study of laser modified titanium and nano-scale surface topographic features. The authors concluded that the torque removal significantly increased in the lasermodified implant and of clinical importance, the nanostructured surfaces supported long-term bone bonding and interface strength between the titanium implant and the bone. The removal torque is also substantially increased. S. S.-Y. L. Kang et al. ${ }^{54}$ studied the biomechanical properties and inter-phase responses of machined and laser-treated stainless steel (SS) implant screws. The laser-treated implants have a higher surface roughness and no compromise in fracture resistance compared to the machined one. The surface roughnesses were increased due to repeated melting and solidification of the material. The bone implant's contact ratio was determined and there was no significant difference between laser-treated and machined micro-screw implants.

\section{CONCLUSIONS}

This article discussed the surface modification methods for titanium alloys in improving the biological properties and friction properties of implants. Based on the above survey, the research spotlight is especially focused on electrochemical anodizing. It can be used for the formation of an oxide layer on a commercially pure Ti surface for dental implants due to the high expectations regarding their applications. The anodization process is a simple and fast surface-modification technique to create a nano-structured $\mathrm{TiO}_{2}$ on the $\mathrm{Ti}$ surface. It will improve the cell growth on the Ti surface. The degree of optimised geometry and surface roughness for implant fixation is still unknown. There is a contradiction in lthe iterature relating in-vivo and in-vitro studies with moderate surface roughness. Some of the researchers mentioned not only the degree of roughness is important; the textured surface of implant is also. There is scope for an evaluation of optimum surface roughness and surface morphology for dental implant applications. This is because the surface roughness plays a major role in quality, the coefficient friction and the rate of osseointegration in titanium dental implants. Aesthetics in this regard refers to the engineering of the surface colour for both marking and implant aesthetic reasons. There is no literature found which investigates the sliding friction behaviours of titanium on titanium with specific reference to the required torque for the axial preloading of titanium screws. Very little research has been conducted on laser surface-modification techniques that investigate its effect on biocompatibility.

\section{FUTURE SCOPE}

From this research gap one can perform research on the aesthetical appearance of dental implants by performing the anodizing process. However, there is no evidence on the statistical relationship between bone contact and surface roughness. Also there is a lack of appropriate measurement on the sliding friction between the titanium on titanium implants with specific reference to the required torque for the axial preloading of titanium screws. Hence, more studies are required to gain knowledge about the aesthetic appearance, surface topography on the bone growth and friction between the bone and titanium implants. The performance of titanium and its alloys can be improved intensely by developing a suitable surface-modification procedure that will lead to increased aesthetic appearance and wear, and frictional properties.

\section{REFERENCES}

${ }^{1}$ J.-L. Delplancke, M. Degrez, A. Fontana, R. Winand, Self-colour anodizing of titanium, Surf. Technol., 16 (1982), 153-162, doi:10.1016/0376-4583(82)90033-4

${ }^{2}$ M. Geetha, A. K. Singh, R. Asokamani, A. K. Gogia, Ti based biomaterials, the ultimate choice for orthopaedic implants - A review, Prog. Mater. Sci., 54 (2009), 397-425, doi:10.1016/j.pmatsci.2008. 06.004

${ }^{3}$ M. V. Wise, D. L., Trantolo, D. J., Lewandrowski, K.-U., Gresser, J. D., Cattaneo, Biomaterials Engineering and Devices: Human Applications, 1st ed., Humana Press, 2000. http://www.springer.com/us/ book/9780896038592

${ }^{4}$ C. N. Elias, J. H. C. Lima, R. Valiev, M. A. Meyers, Biomedical Applications of Titanium and its Alloys, J. Miner. Met. Mater. Soc., (2008), 46-49, doi:10.1007/s11837-008-0031-1

${ }^{5}$ K. Maehara, K. Doi, T. Matsushita, Y. Sasaki, Application of Vanadium-Free Titanium Alloys to Artificial Hip Joints, Mater. Trans., 43 (2002), 2936-2942, doi:10.2320/matertrans.43.2936

${ }^{6}$ M. Long, H. J. Rack, Titanium alloys in total joint replacement-a materials science perspective., Biomaterials., 19 (1998), 1621-1639, doi:10.1016/S0142-9612(97)00146-4

${ }^{7}$ M. Niinomi, M. Nakai, J. Hieda, Development of new metallic alloys for biomedical applications, Acta Biomater., 8 (2012), 3888-3903, doi:10.1016/j.actbio.2012.06.037 
${ }^{8}$ K. Subramani, R. T. Mathew, Titanium Surface Modification Techniques for Dental Implants-From Microscale to Nanoscale, First Edit, Elsevier Inc., 2012, doi:10.1016/B978-1-4557-7862-1.00006-7

${ }^{9}$ J.-K. Lee, D.-S. Choi, I. Jang, W.-Y. Choi, Improved osseointegration of dental titanium implants by $\mathrm{TiO}_{2}$ nanotube arrays with recombinant human bone morphogenetic protein-2: a pilot in vivo study, International Journal of Nanomedicine, 10 (2015), 1145-1154, doi:10.2147/IJN.S78138

${ }^{10}$ A. Karambakhsh, A. Afshar, S. Ghahramani, P. Malekinejad, Pure commercial titanium color anodizing and corrosion resistance, J. Mater. Eng. Perform., 20 (2011), 1690-1696, doi:10.1007/s11665011-9860-0

${ }^{11}$ H. J. Song, M. K. Kim, G. C. Jung, M. S. Vang, Y. J. Park, The effects of spark anodizing treatment of pure titanium metals and titanium alloys on corrosion characteristics, Surf. Coatings Technol., 201 (2007), 8738-8745, doi:10.1016/j.surfcoat.2006.11.022

${ }^{12}$ D. G. Bansal, O. L. Eryilmaz, P. J. Blau, Surface engineering to improve the durability and lubricity of Ti-6Al-4V alloy, Wear., 271 (2011), 2006-2015, doi:10.1016/j.wear.2010.11.021

${ }^{13}$ A. Vadiraj, M. Kamaraj, Fretting fatigue behavior of surface modified biomedical titanium alloys, Trans. Indian Inst. Met., 63 (2010), 217-223, doi:10.1007/s12666-010-0030-0

${ }^{14}$ A. Wennerberg, T. Albrektsson, J. Lausmaa, Torque and histomorphometric evaluation of c.p. titanium screws blasted with 25- and 75-m-sized particles of $\mathrm{Al}_{2} \mathrm{O}_{3}$, J. Biomed. Mater. Res., 30 (1996), 251-260, doi:10.1002/(SICI)1097-4636(199602)30:2<251:AIDJBM16>3.0.CO;2-P

${ }^{15}$ G. Peto, A. Karacs, Z. Pászti, L. Guczi, T. Divinyi, A. Joób, Surface treatment of screw shaped titanium dental implants by high intensity laser pulses, Appl. Surf. Sci., 186 (2002), 7-13, doi:10.1016/S01694332(01)00769-3

${ }^{16}$ L. Le Guéhennec, A. Soueidan, P. Layrolle, Y. Amouriq, Surface treatments of titanium dental implants for rapid osseointegration, Dent. Mater., 23 (2007), 844-854, doi:10.1016/j.dental.2006.06.025

${ }^{17}$ A. Abron, M. Hopfensperger, J. Thompson, L. F. Cooper, Evaluation of a predictive model for implant surface topography effects on early osseointegration in the rat tibia model, J. Prosthet. Dent., 85 (2001), 40-46, doi:10.1067/mpr.2001.112415

${ }^{18}$ S. A. Novaes AB Jr, Souza SL, de Oliveira PT, Histomorphometric analysis of the bone-implant contact obtained with 4 different implant surface treatments placed side by side in the dog mandible, Int J Oral Maxillofac Implant., 17 (2002), 377-83

${ }^{19}$ M. Piattelli, A. Scarano, M. Paolantonio, G. Iezzi, G. Petrone, A Piattelli, Bone response to machined and resorbable blast material titanium implants: an experimental study in rabbits, J. Oral Implantol., 28 (2002), 2-8, doi:10.1563/1548-1336(2002)028<0002: BRTMAR $>2.3 . \mathrm{CO} ; 2$

${ }^{20}$ W.-D. Müeller, U. Gross, T. Fritz, C. Voigt, P. Fischer, G. Berger, et al., Evaluation of the interface between bone and titanium surfaces being blasted by aluminium oxide or bioceramic particles., Clin. Oral Implants Res., 14 (2003), 349-356, doi:10.1034/j.1600-0501.2003. 00791.x

${ }^{21}$ A. Karacs, A. Joob Fancsaly, T. Divinyi, G. Peto, G. Kovách, Morphological and animal study of titanium dental implant surface induced by blasting and high intensity pulsed Nd-glass laser, Mater. Sci. Eng. C., 23 (2003), 431-435, doi:10.1016/S0928-4931(02) 00316-8

${ }^{22}$ C. Larsson, L. Emanuelsson, P. Thomsen, L. E. Ericson, B.-O. Aronsson, B. Kasemo et al., Bone response to surface-modified titanium implants: studies on the early tissue response to machined and electropolished implants with different oxide thicknesses, Biomaterials., 17 (1996) 605-616, doi:10.1016/0142-9612(96) 88711-4

${ }^{23}$ H. Badekas, C. Panagopoulos, Titanium anodization under constant voltage conditions, Surface \& Coatings Technology, 31 (1987), 381-388, doi: 10.1016/0257-8972(87)90164-2
${ }^{24}$ A. K. Sharma, Anodizing titanium for space applications, Thin Solid Films, 208 (1992), 48-54, doi:10.1016/0040-6090(92)90946-9

${ }^{25}$ M. Shirkhanzadeh, Electrochemical preparation of protective oxide coatings on titanium surgical alloys, J. Mater. Sci. Mater. Med., 3 (1992), 322-325, doi:10.1007/BF00705362

${ }^{26}$ Z. M. Yan, T. W. Guo, H. B. Pan, J. J. Yu, Influences of Electrolyzing Voltage on Chromatics of Anodized Titanium Dentures., Mater. Trans., 43 (2002), 3142-3145, doi:10.2320/matertrans. 43.3142

${ }^{27}$ Z. Huan, L. E. Fratila-Apachitei, I. Apachitei, J. Duszczyk, Synthesis and characterization of hybrid micro/nano-structured NiTi surfaces by a combination of etching and anodizing., Nanotechnology, 25 (2014), 055602, doi:10.1088/0957-4484/25/5/055602

${ }^{28}$ H. Song, S. Park, S. Jeong, Y. Park, Surface characteristics and bioactivity of oxide films formed by anodic spark oxidation on titanium in different electrolytes, J. Mater. Process. Tech., 9 (2008), 864-870, doi:10.1016/j.jmatprotec.2008.02.055

${ }^{29}$ J. P. Schreckenbach, G. Marx, Characterization of anodic spark-converted titanium surfaces for biomedical applications, Journal of materials science: Materials in medicine, 10 (1999), 453-457, doi:10.1023/A:1008988706980

${ }^{30}$ A. Zhecheva, S. Malinov, W. Sha, Titanium alloys after surface gas nitriding, Surf. Coatings Technol., 201 (2006), 2467-2474, doi:10.1016/j.surfcoat.2006.04.019

${ }^{31}$ K. Kim, B. A. Lee, X. H. Piao, H. J. Chung, Y. J. Kim, Surface characteristics and bioactivity of an anodized titanium surface, J. Periodontal Implant Sci., 43 (2013), 198-205, doi:10.5051/jpis.2013. 43.4.198

${ }^{32}$ C. N. Elias, Biomedical Applications of Titanium and its Alloys, Rev. Mater., 15 (2010), 138-142, doi:10.1007/s11837-008-0031-1

${ }^{33}$ B. C. de V. Gurgel, P. F. Gonçalves, S. P. Pimentel, F. H. Nociti, E. A. Sallum, A. W. Sallum et al., An Oxidized Implant Surface May Improve Bone-to-Implant Contact in Pristine Bone and Bone Defects Treated With Guided Bone Regeneration: An Experimental Study in Dogs, J. Periodontol., 79 (2008), 1225-1231, doi:10.1902/ jop.2008.070529

${ }^{34}$ P. M. Burgos, L. Rasmusson, L. Meirelles, L. Sennerby, Early bone tissue responses to turned and oxidized implants in the rabbit tibia, Clin. Implant Dent. Relat. Res., 10 (2008), 181-190, doi:10.1111/ j.1708-8208.2007.00074.x

${ }^{35}$ E. T. Uzumaki, A. R. Santos, C. S. Lambert, Titanium Oxide $\left(\mathrm{TiO}_{2}\right)$ Coatings Produced on Titanium by Oxygen-Plasma Immersion and Cell Behaviour on TiO2, Key Eng. Mater., 309-311 (2006), 367-370, doi:10.4028/www.scientific.net/KEM.309-311.367

${ }^{36}$ C. Yao, T. J. Webster, Anodization: a promising nano-modification technique of titanium implants for orthopedic applications., J. Nanosci. Nanotechnol., 6 (2006), 2682-92, http://www.ncbi.nlm.nih. gov/pubmed/17048475

${ }^{37}$ M. Sato, T. J. Webster, Nanobiotechnology: implications for the future of nanotechnology in orthopedic applications., Expert Rev. Med. Devices., 1 (2004), 105-14, doi:10.1586/17434440.1.1.105

${ }^{38}$ E. Vermesse, C. Mabru, L. Arurault, Surface integrity after pickling and anodization of Ti-6Al-4V titanium alloy, Appl. Surf. Sci., 285 (2013), 629-637, doi:10.1016/j.apsusc.2013.08.103

${ }^{39}$ L. Wu, J. Liu, M. Yu, S. Li, H. Liang, M. Zhu, Effect of Anodization time on Morphology and Electrochemical Impedance of Andic Oxide Films on Titanium Alloy in Tartrate Solution, Int. J. Electrochem. Sci., 9 (2014), 5012-5024

${ }^{40}$ Y. T. Sul, Electrochemical growth behavior, surface properties, and enhanced in vivo bone response of $\mathrm{TiO}_{2}$ nanotubes on microstructured surfaces of blasted, screw-shaped titanium implants, Int. J. Nanomedicine., 5 (2010), 87-100, doi:10.2147/IJN.S8012

${ }^{41}$ K. Yokoyama, T. Ichikawa, H. Murakami, Y. Miyamoto, K. Asaoka, Fracture mechanisms of retrieved titanium screw thread in dental implant, Biomaterials., 23 (2002), 2459-2465, doi:10.1016/S01429612(01)00380-5 


\section{MATERIALI IN TEHNOLOGIJE/MATERIALS AND TECHNOLOGY (1967-2017) - 50 LET/50 YEARS}

\section{MANJAIAH, R. F. LAUBSCHER: A REVIEW OF THE SURFACE MODIFICATIONS OF TITANIUM ALLOYS ...}

${ }^{42}$ F. Javed, G.E. Romanos, The role of primary stability for successful immediate loading of dental implants, A literature review, J. Dent., 38 (2010), 612-620, doi:10.1016/j.jdent.2010.05.013

${ }^{43}$ M. V. dos Santos, C. N. Elias, J. H. Cavalcanti Lima, The effects of superficial roughness and design on the primary stability of dental implants, Clin. Implant Dent. Relat. Res., 13 (2011), 215-223, doi:10.1111/j.1708-8208.2009.00202.x

${ }^{44}$ C. N. Eliasa, F. A. Rocha, A. L. Nascimento, P. G. Coelho, Influence of implant shape, surface morphology, surgical technique and bone quality on the primary stability of dental implants, J. Mech. Behav. Biomed. Mater., 16 (2012), 169-180, doi:10.1016/j.jmbbm.2012. 10.010

${ }^{45}$ Y. Oshida, Surface modifications; Bioscience and Bioengineering of Titanium Materials, 2007, doi:10.1016/B978-008045142-8/50011-6

${ }^{46}$ H. Garg, G. Bedi, Implant Surface Modifications?: A Review, J. Clin. Diagnostic Res., 6 (2012), 319-324

${ }^{47}$ A. M. Ballo, O. Omar, W. Xia, A. Palmquist, Implant Dentistry - A Rapidly Evolving Practice, Implant Dent. - A Rapidly Evol. Pract., (2011), 19-56, doi:10.5772/706

${ }^{48}$ C. Larsson, P. Thomsen, B. O. Aronsson, M. Rodahl, J. Lausmaa, B. Kasemo et al., Bone response to surface modified titanium implants: Studies on the early tissue response to machined and electropolished implants with different oxide thicknesses, Biomaterials., 17 (1996), 605-616, doi:10.1016/0142-9612(96)88711-4
${ }^{49} \mathrm{~S}$. Cho, S. Jung, A removal torque of the laser-treated titanium implants in rabbit tibia, Biomaterials., 24 (2003), 4859-4863, doi:10.1016/S0142-9612(03)00377-6

${ }^{50}$ A. Gaggl, G. Schultes, W. D. Mu, H. Ka, Scanning electron microscopical analysis of laser-treated titanium implant surfaces - a comparative study, Biomaterials., 21 (2000), 1067-1073, DOI:10.1016/s0142-9612(00)00002-8

${ }^{51}$ F. J. Gil, L. Delgado, E. Espinar, J. M. Llamas, Corrosion and corrosion-fatigue behavior of cp-Ti and $\mathrm{Ti}-6 \mathrm{Al}-4 \mathrm{~V}$ laser-marked biomaterials, J Mater Sci Mater Med., 23 (2012), 885-890, doi:10.1007/s10856-012-4572-z

${ }^{52}$ G. Romanos, M. Dent, R. Crespi, D. D. S. A. Barone, D. D. S. U. Covani, Osteoblast Attachment on Titanium Disks After Laser Irradiation, Int. J. Oral Maxillofac. Implant., 21 (2006), 232-236

${ }^{53}$ A. Palmquist, O. M. Omar, M. Esposito, Titanium oral implants: surface characteristics, interface biology and clinical outcome, J. R. Soc. Interface., 7 (2010), 515-527, doi:10.1098/rsif.2010.0118.focus ${ }^{54}$ S. S.-Y. L. He-Kyong Kang, T.-M. Chu, P. Dechow, Kelton Stewart, H.-M. Kyung, Laser-treated stainless steel mini-screw implants_3D surface roughness, bone-implant contact, and fracture resistance analysis, Eur. J. Orthod., 37 (2015), doi:10.1093/ejo/cjv017 